\title{
Faktor-Faktor Yang Mempengaruhi Keputusan Pembelian Air Mineral Dalam Kemasan Merek Dharma (Studi Kasus pada Konsumen CV. Bahana Tirta Alam Maritim di Kabupaten Sumbawa Besar)
}

\author{
Abdurrahman', Wiwin Andriani2 \\ Program Studi Manajemen Universitas Bumigora Mataram ${ }^{1}$ \\ Program Studi Manajemen Universitas Teknologi Sumbawa² \\ Email: abdurrahmanarman77@gmail.com
}

\begin{abstract}
Abstrak
Penelitian ini bertujuan untuk mengetahui: 1) pengaruh kualitas produk terhadap keputusan pembelian AMDK Merek Dharma. 2) pengaruh harga terhadap keputusan pembelian AMDK Merek Dharma. 3) pengaruh promosi terhadap keputusan pembelian AMDK Merek Dharma. 4) pengaruh kualitas produk, harga, dan promosi secara simultan terhadap keputusan pembelian AMDK Merek Dharma. Model yang digunakan dalam analisis data adalah uji instrumen penelitian, uji asumsi klasik, analisis regresi berganda, dan uji hipotesis. Alat analisis yang digunakan dalam penelitian ini adalah SPSS 16. Data yang digunakan yaitu data primer dan data skunder dengan pengambilan sampel secara purposive sampling. Hasil penelitian menunjukan bahwa 1) kualitas produk berpengaruh positif dan signifikan yang di tunjukan dengan nilai untuk variabel kualitas produk ialah sebesar 0.000 dimana nilai ini < 0,05. 2) Harga berpengaruh positif tetapi tidak signifikan yang ditunjukan dengan nilai untuk variabel harga ialah sebesar 0.820 dimana nilai ini $>$ dari 0,05. 3) Promosi berpengaruh positif dan signifikan yang ditunjukan dengan nilai untuk variabel promosi ialah sebesar 0.005 dimana nilai ini $<0,05$. Secara simultan kualitas produk, harga, dan promosi mempengaruhi keputusan pembelian sebesar $31,0 \%$.
\end{abstract}

Keywords : product quality, price, promotion, and purchasing decision 


\section{Pendahuluan}

Perubahan perilaku masyarakat yang semakin mengarah ke berbagai hal praktis menjadi peluang tersendiri bagi pelaku bisnis. Hal tersebut memunculkan banyak produk bisnis dalam kemasan yang praktis menjadi marak dalam persaingan. Begitu pula dengan bisnis Air Minum Dalam Kemasan atau yang umum di kenal dengan AMDK yang semakin berkembang. Maraknya bisnis di industri AMDK ini di dasari oleh kebutuhan atas AMDK yang semakin penting di kalangan masyarakat, mengingat ketersediaan air bersih di beberapa tempat sangat terbatas. AMDK menjadi pilihan masyarakat untuk memenuhi kebutuhan air minum mereka. Hal ini di pandang sebagai bisnis yang menjadi kebutuhan bagi konsumen sehingga menjadikan bisnis di industri ini meningkat dengan pesat dan adanya persaingan yang semakin ketat.Ketatnya persaingan membuat para pebisnis harus pandai mengelola bisnis yang dijalani, supaya tetap eksis dan berkembang (Abdullah, 2016:21).

Keadaan masyarakat kota saat ini yang mulai resah dalam mencari sumber air bersih, menjadi kesempatan bagi pengusaha AMDK untuk bisa meningkatkan penjualan produk mereka yang membuat bisnis air minum dalam kemasan menjadi kebutuhan. Hal ini tidak terlepas dari keinginan konsumen yang selalu menginginkan untuk memperoleh barang-barang dengan kualitas baik, sehingga perusahaan-perusahaan yang ada sekarang ini harus mempunyai keunggulan daya saing bagi setiap produk-produknya (Setiadi, 2011:11).

Menurut Kotler, (2009:29)salah satu keunggulan dalam persaingan pada suatu perusahaan adalah kualitas produk yang dapat memenuhi keinginan dan kebutuhan konsumen. Bila tidak sesuai dengan spesifikasi maka produk akan ditolak, sekalipun produk tersebut masih dalam batas toleransi yang telah ditentukan maka produk tersebut sebaiknya perlu menjadi catatan untuk menghindari terjadinya kesalahan yang lebih besar diwaktu yang akan datang. Kondisi pelanggan yang semakin kritis dalam hal kualitas juga memaksa perusahaan untuk dapat mempertahankan dan meningkatkan mutu produknya agar terhindar dari klaim atau ketidakpuasaan pelanggan perusahaan agar dapat bersaing dengan perusahaan lain yang sejenis.

Belakangan ini bisnis AMDK semakin menggiurkan, karena kebutuhan akan air minum terus meningkat seiring dengan pertumbuhan penduduk. AMDK merupakan barang konsumen (consumers goods) ditinjau dari cara pemanfaatan oleh konsumen, yaitu barang yang dibeli oleh konsumen akhir untuk kepentingan pribadi. Berdasarkan caracara konsumen membeli suatu barang, AMDK tergolong barang nyaman (convinience goods) yaitu barang konsumen yang sering dibeli dan kadang kala bersifat segera. Oleh karena itu Perusahaan yang menggarap bisnis AMDK pun semakin banyak dan terus melakukan ekspansi untuk memperluas jaringan pasar produk-produknya. Bayangkan saja kebutuhan masyarakat akan air minum sangat tinggi, sedangkan ketersedian air yang layak minum dalam arti berkualitas dan terjamin dari segi kesehatan semakin sulit diperoleh (Abdullah, 2016:32).

\section{Studi Literatur}




\section{Kualitas Produk}

Menurut Sofian, (2011:21) kualitas adalah karakteristik dari produk dalam kemampuan untuk memenuhi kebutuhan-kebutuhan yang telah ditentukan dan bersifat laten. Kualitas dalam pandangan konsumen adalah hal yang mempunyai ruang lingkup tersendiri yang berbeda dengan kualitas dalam pandangan produsen saat mengeluarkan suatu produk yang biasa dikenal kualitas sebenarnya. Kualitas produk dibentuk oleh beberapa indikator antara lain kemudahaan pengguna, daya tahan, kejelasan fungsi, keragaman, ukuran produk dan lain-lain. Kualitas merupakan keseluruhan ciri serta sifat suatu produk atau pelayanan yang berpengaruh pada kemampuanya untuk memuaskan kebutuhan yang dinyatakan maupun yang tersirat.

\section{Harga}

Harga merupakan salah satu atribut penting yang dievaluasi oleh konsumen sehingga manajer perusahaan perlu benar-benar memahami peran tersebut dalam mempengaruhi sikap konsumen. Harga sebagai atribut dapat diartikan bahwa harga merupakan konsep keanekaragaman yang memiliki arti berbeda bagi tiap konsumen, tergantung karakteristik konsumen, situasi dan produk. Dengan kata lain, pada tingkat harga tertentu yang telah dikeluarkan, konsumen dapat merasakan manfaat dari produk yang telah dibelinya. Dan konsumen akan merasa puas apabila manfaat yang mereka dapatkan sebanding atau bahkan lebih tinggi dari nominal uang yang mereka keluarkan (Saladin, 2008:95)

\section{Promosi}

Dalam mengelola suatu sistem komunikasi pemasaran memerlukan suatu rancangan strategi dan program-program penjualan yang efektif dan efisien. Promosi penjualan merupakan unsur kunci dalam kampanye perusahaan dan promosi yang paling baik adalah promosi yang dilakukan oleh pelanggan yang puas. Dengan demikian, promosi perlu ditangani secara cermat karena masalahnya bukan hanya menyangkut pada bagaimana berkomunikasi dengan pelanggan akan tetapi juga menyangkut seberapa besar biaya yang akan dikeluarkan oleh perusahaan yang tentunya harus disesuaikan pada kondisi dan kemampuan perusahaan (Kristanto, 2016:67).

\section{Keputusan Pembelian}

Dalam mengenal konsumen perlu mempelajari perilaku konsumen sebagai perwujudan dari seluruh aktivitas jiwa manusia dalam kehidupan sehari hari. Persepsipersepsi pengaruh orang lain dan motivasi-motivasi internal akan berinteraksi untuk menentukan keputusan terakhir yang dianggap paling sesuai (Swastha, 2010:141). 


\section{Kerangka Konseptual Dan Hipotesis Penelitian}

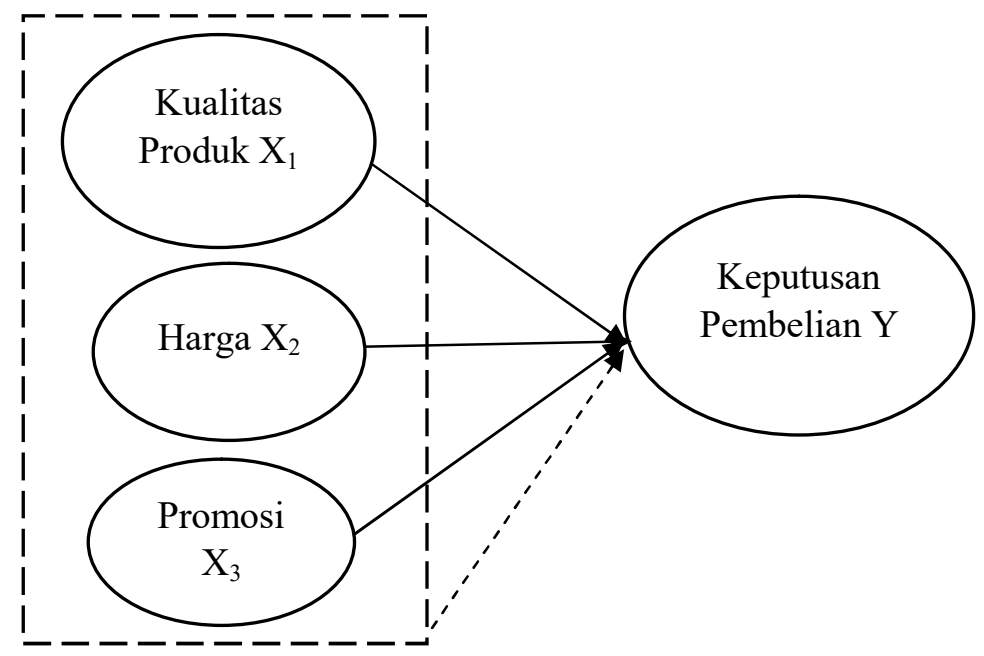

Sumber: Dikembangkan dalam penelitian ini, 2019

Keterangan :

\section{Gambar 2.2. Kerangka Konseptual}

$\longrightarrow$ : Pengaruh masing-masing variabel independen terhadap variabel dependen secara parsial

---- : Pengaruh variabel independen terhadap variabel dependen secara simultan

\section{Hipotesis}

$\mathrm{H}_{1}$ : Kualitas Produk Berpengaruh Positif dan Signifikan Terhadap Keputusan Pembelian. $\mathrm{H}_{2}$ :Harga Berpengaruh Positif Terhadap Keputusan Pembelian.

$\mathrm{H}_{3}$ :Promosi Berpengaruh Positif dan Signifikan Terhadap Keputusan Pembelian.

$\mathrm{H}_{4}$ :Terdapat Pengaruh Secara Simultan dari Variabel Kualitas Produk, Harga, dan Promosi

Terhadap Keputusan Pembelian. 


\section{Metode Penelitian}

Penelitian ini merupakan penelitian yang menggunakan pendekatan metode kuantitatif. Pendekatan kuantitatif dapat diartikan sebagai metode penelitian yang digunakan untuk meneliti pada populasi atau sampel tertentu. Penelitian ini termasuk penelitian survei.Populasi dalam penelitian ini yaitu seluruh konsumen air minum dalam kemasan merek dharma pada CV. Bahana Tirta Alam Maritim di Kab. Sumbawa. Sampel dari penelitian ini adalah bagian kecil dari karakteristik yang dimiliki oleh populasi tersebut. Metode penentuan sampel yang digunakan adalah purposive sampling yang dipilih berdasarkan kriteria-kriteria tertentu.

\section{Teknik Analisis Data}

Metode analisis data yang digunakan dalam penelitian ini adalah menggunakan uji instrumen penelitian, uji asumsi klasik, uji analisis regresi linier berganda dan uji hipotesis. Interpretasi hasil penelitian baik secara parsial melalui uji-t maupun secara simultan melalui uji-F. Alat analisis yang digunakan SPSS 16.

\section{Hasil Dan Pembahasan}

\section{Hasil Uji Instrumen Penelitian}

\section{Uji Validitas}

Uji validitas dilakukan dengan membandingkan nilai $r_{\text {hitungdengan }} r_{\text {tabelapabila }}$ rhitung lebih besar dari $r_{\text {tabel }}$ (pada taraf signifikansi 0.05), maka dapat dikatakan item kuesioner tersebut valid, tetapi jika rhitunglebih kecil dari $r_{\text {tabel }}$ maka butir pernyataan tersebut tidak valid.Penelitian ini menghasilkan nilai $r_{\text {hitung }}>$ dari pada $r_{\text {tabelsebesar }}$ 0,850 > 0,196 sehingga dapat disimpulkan bahwa semua instrumen dalam penelitian ini dapat dikatakan valid.

\section{Uji Reliabilitas}

Pengujian reliabilitas terhadap seluruh item atau pernyataan pada penelitian ini menggunakan rumus koefisien Cronbach Alpha. Nilai Cronbach Alpha pada penelitian ini akan digunakan nilai 0,6 dengan asumsi bahwa daftar pernyataan yang di uji akan di katakan reliabel bila nilai Cronbach Alpha $\geq 0,6$. Masing-masing variabel dalam Penelitian ini menghasilkan nilai Cronbach Alpha yang lebih besar dari 0,6 dimana nilainya sebesar $0,777>0,6$. Kondisi ini menunjukan bahwa seluruh variabel tersebut adalah reliabel dan dapat digunakan pada analisis selanjutnya.

\section{Hasil Uji Asumsi Klasik \\ 1. Uji Normalitas}

Uji normalitas pada penelitian ini menggunakan Kolmogorov Smirnov(K-S). Dalam uji ini apabila nilai sig < 0,05 maka data tidak terdistribusi dengan normal. Namun jika nilai sig > 0,05 maka data terdistribusi dengan normal. Hasil uji normalitas yang 
menggunakan metode Kolmogorov-Smirnovdi dapatkan hasil signifikansi dari uji normalitas sebesar 0,611 dimana hasil tersebut lebih besar dari taraf signifikansi 0.05, sehingga dapat disimpulkan bahwa uji normalitas pada penelitian ini adalah terdistribusi normal.

\section{Uji Multikolinearitas}

Ada tidaknya multikolinearitas dapat dilihat dari besarnya Variance Infalation Factor (VIF) dan nila Tolerance. Yaitu jika tolerance value $\leq 0.10$ atau VIF $\geq 0.10$ maka tidak terjadi multikolinearitas. dari hasil uji multikolinearitas yang dilakukan dalam penelitian menunjukan bahwa variabel kualitas produk (X1) dengan nilai tolerance $0.959>0.10$ dan nilai VIF $1.043<10$, variabel harga $(X 2)$ dengan nilai tolerance $0.995>0.10$ dan nilai VIF $1.005<10$, dan variabel promosi (X3) dengan nilai tolerance $0.963>0.10$ dan nilai VIF $1.038<10$. Maka dapat disimpulkan bahwa semua variabel bebas tidak terjadi multikolinearitas.

\section{Uji Heteroskedastisitas}

Berdasarkan hasil uji gelejser di peroleh nilai probabilitas sebesar 0.510 alpha 0.05, maka dapat disimpulkan tidak terjadi heterokedastisitas.

\section{Hasil Uji Analisis Regresi Linier Berganda}

Analisis regresi linier berganda pada penelitian ini di gunakan untuk mengetahui pengaruh kualitas produk(X1), harga (X2) dan promosi (X3) terhadap keputusan pembelian $(\mathrm{Y})$. Hasil persamaan regresi berganda adalah sebagai berikut:

a) Nilai konstanta sebesar 2.434 menunjukan bahwa ketika nilai variabel independen yaitu variabel kualitas produk, harga, dan promosi diasumsikan tetap, maka nilai keputusan pembelian sebesar 2.434 .

b) Nilai koefisien regresi variabel kualitas produk bernilai positif yaitu 0.239 menunjukan apabila nilai kualitas produk mengalami kenaikan satu satuan sementara variabel independen lainnya diasumsikan tetap, maka nilaikeputusan pembelian akan meningkat sebesar 0.239 .

c) Nilai koefisien regresi variabel harga bernilai positif yaitu 0.011 menunjukan apabila nilai hargamengalami kenaikan satu satuan sementara variabel independen lainnyadiasumsikan tetap, maka nilaikeputusan pembelian akan meningkat sebesar 0.011 .

d) Nilai koefisien regresi variabel promosi bernilai positif yaitu 0.246 menunjukan apabila nilai promosi mengalami kenaikan satu satuan sementara variabel independen lainnya diasumsikan tetap, maka nilai keputusan pembelian akan meningkat sebesar 0.246

e)

\section{Hasil Uji Hipotesis}

1. Uji t (Uji Parsial)

Uji t dalam penelitian ini menggunakan tingkat signifikansi 0.05 , jika nilai sig $>0.05$ maka Ho ditolak dan Ha diterima, sedangkan jika nilai sig < 0,05 maka Ho diterima dan Ha ditolak. 
Hipotesis 1: Kualitas Produk Berpengaruh Positif dan Signifikan Terhadap Keputusan Pembelian.

Berdasarkan hasil uji $\mathrm{t}$ dapat dilihat bahwa nilai $\mathrm{t}_{\text {hitung }}$ variabel kualitas produk sebesar 5.197, dimana $t_{\text {hitung }}>t_{\text {tabel }}(5.197>1.984)$ dengan nilai signifikansi $0.000<0.05$. Maka Ho ditolak dan Ha diterima, sehingga dapat di simpulkan bahwa terdapat hubungan positif dan signifikan antara kualitas produk dengan keputusan pembelian.

Hipotesis 2: Harga Berpengaruh Positif Terhadap Keputusan Pembelian.

Berdasarkan hasil uji t dapat dilihat bahwa nilai thitung variabel harga sebesar 0.288, dimana thitung $>t_{\text {tabel }}(0.288<1.984)$ dengan nilai signifikansi $0.820<0.05$. Maka Ho diterima dan Ha ditolak, sehingga dapat di simpulkan bahwa terdapat hubungan positif tetapi tidak signifikan antara harga dengan keputusan pembelian.

Hipotesis 3: Promosi Berpengaruh Positif dan Signifikan Terhadap Keputusan Pembelian.

Berdasarkan hasil uji t dapat dilihat bahwa nilai thitung variabel promosi sebesar 2.886, dimana $t_{\text {hitung }}>t_{\text {tabel }}(2.886>1.984)$ dengan nilai signifikansi $0.005<0.05$. Maka Ho ditolak dan Ha diterima, sehingga dapat di simpulkan bahwa terdapat hubungan positif dan signifikan antara promosi dengan keputusan pembelian.

2. Uji F (Uji Simultan)

Berdasarkan hasil uji F dapat dilihat bahwa nilai $F_{\text {hitung }}>F_{\text {tabel }}(14.346>2.70)$ dengan nilai signifikansi $0.000<0.05$, maka dapat disimpulkan bahwa terdapat pengaruh positif dan signifikan secara bersama-sama antara kualitas produk (X1), harga (X2), dan promosi (X3) terhadap keputusan pembelian (Y)

3. Koefisien Determinasi $\left(\mathrm{R}^{2}\right)$

menunjukan bahwa nilai $\mathrm{R}$ square sebesar 0.310. Hasil ini membuktikan bahwa pengaruh kualitas produk, harga, dan promosi terhadap keputusan pembelian sebesar $31.0 \%$ dan sisanya $69.0 \%$ di pengaruhi oleh faktor-faktor lain diluar variabel yang digunakan dalam penelitian ini.

\section{Pembahasan}

\section{Pengaruh Kualitas Produk Terhadap Keputusan Pembelian}

Berdasarkan hasil uji hipotesis menggunakan uji parsial (Uji $t$ ), yang telah dijelaskan di atas menunjukkan bahwa $\mathrm{H}_{1}$ diterima, yang diketahui bahwa terdapat pengaruh positif secara signifikan antara kualitas produk terhadap keputusan pembelian, yang berarti bahwa semakin tinggi kualitas produk AMDK Merek Dharma, maka keputusan pembelian AMDK Merek Dharma oleh konsumen juga akan semakin tinggi. Hal ini menunjukkan bahwa keputusan pembelian berpengaruh oleh kualitas produk, dimana kualitas produk menjadi pertimbangan dalam proses pengambilan keputusan dalam melakukan pembelian air minum dalam kemasan merek Dharma di Kabupaten Sumbawa. 
Kondisi diatas disebabkan oleh beberapa hal yang membuat kualitas produk berpengaruh positif dan signifikan terhadap keputusan pembelian antara lain, pertamaposisi AMDK Merek Dharma tersebut menjadi kategori produk dengan merek yang memiliki brand image yang tinggi dikalangan masyarakat selain itu produknya juga dikenal masyrakat sejak dahulu sehingga konsumen tidak memperhatikan kualitas produk yang dimiliki. Keduapersaingan yang tinggi di industri AMDK terutama di Kabupaten Sumbawa yang membuat banyaknya pilihan yang harus dipilih oleh konsumen dalam mengambil keputusan pembelian AMDK sehingga konsumen hanya berpatokan pada kualitas produk, harga, dan promosi yang ditawarkan perusahaan sesuai dengan kemampuan daya beli masyarakat. Ketigapengetahuan konsumen terhadap kualitas produk yang dimiliki oleh Dharma itu cukup luashal ini sesuai dengan kualitas produk yang telah ditawarkan oleh perusahaan.

\section{Pengaruh Harga Terhadap Keputusan Pembelian}

Berdasarkan hasil uji hipotesis menggunakan uji parsial (Uji t), telah terbukti bahwa pengujian hipotesis 2 ditolak berdasarkan hasil uji tersebut harga berada pada daerah positif atau baik. Harga menentukan berhasilnya suatu produk terjual dengan baik di pangsa pasar, perusahaan sudah memperhatikan pemberian harga terhadap produk AMDK Merek Dharma dimana harga AMDK Merek Dharma sesuai dengan produk, harga AMDK Merek Dharma terjangkau, harga dapat bersaing dengan produk lainnya, harga sesuai dengan manfaat. akan hal ini menunjukkan bahwa keputusan pembelian tidak terpengaruh oleh harga, dimana harga tidak menjadi pertimbangan konsumen dalam proses pengambilan keputusan dalam melakukan pembelian air minum dalam kemasan merek Dharma di Kabupaten Sumbawa.Kondisi diatas disebabkan oleh beberapa hal yang membuat harga tidak berpengaruh terhadap keputusan pembelian antara lain, pertamaharga tidak menjadikan patokan bagi konsumen untuk bisa mengambil keputusan pembelian terhadap suatu produk, karena AMDK Merek Dharma tersebut termasuk kategori produk yang memiliki harga yang tidak sesuai dengan manfaat produknya. Keduapersaingan yang tinggi di industri AMDK terutama di Kabupaten Sumbawa yang membuat banyaknya pilihan yang harus dipilih oleh konsumen dalam mengambil keputusan pembelian AMDK sehingga konsumen hanya berpatokan pada kualitas produk dan promosi yang ditawarkan perusahaan sesuai dengan kemampuan daya beli masyarakat. Ketigaminimnya pengetahuan konsumen terhadap harga yang di tawarkan oleh perusahaan AMDK Merek Dharma.

\section{Pengaruh Promosi Terhadap Keputusan Pembelian}

Berdasarkan hasil uji hipotesis menggunakan uji parsial (Uji t), yang telah dijelaskan di atas menunjukkan bahwa H3 diterima, yang berarti terdapat pengaruh positif secara signifikan antara promosi terhadap keputusan pembelian. Hal ini menunjukkan bahwa keputusan pembelian berpengaruh oleh promosi, dimana promosi menjadi pertimbangan dalam proses pengambilan keputusan dalam melakukan pembelian air 
minum dalam kemasan merek Dharma di Kabupaten Sumbawa. Promosi adalah salah satu bentuk komunikasi untuk memenuhi fungsi pemasaran.

Kondisi diatas disebabkan oleh beberapa hal yang membuat promosi berpengaruh positif dan signifikan terhadap keputusan pembelian antara lain, pertamaAMDK Merek Dharma melakukan promosi dengan baik sehingga mampu menarik konsumen untuk melakukan pembelian terhadap AMDK Merek Dharma. Kedua kegiatan promosi sangatlah berperan penting dalam keputusan pembelian, karena perusahaan menggunakan promosi untuk meningkatkan penjualan produknya. Oleh karena itu perusahaan harus lebih cerdas dan inovatif lagi dalam meningkatkan promosinya agar dapat menarik konsumen sehingga keputusan pembelian konsumen dalam membeli produk air minum Dharma semakin meningkat.

\section{Pengaruh Kualitas Produk, Harga, dan Promosi Terhadap Keputusan Pembelian}

Berdasarkan hasil analisis data diketahui bahwa variabel kualitas produk, harga, dan promosi berpengaruh positif dan signifikan secara simultan terhadap keputusan pembelian. Dalam mempengaruhi keputusan pembelian ada beberapa yang harus di perhatikan oleh sebuah perusahaan, pertama perusahaan harus memberikan kualitas produk yang bagus kepada para konsumennya. Kedua perusahaan harus memberikan harga yang sesuai dengan kualitas yang diterima oleh konsumen, selain itu promosi juga memiliki peran penting dalam sebuah perusahaan untuk memperkenalkan produknya kepada masyarakat luas.

Cara agar dapat mempengaruhi keputusan pembelian, air Dharma harus terus berusaha meningkatkan lagi kualitas produk, harga, serta promosi. Sehingga konsumen yakin untuk melakukan pengambilan keputusan pembelian terhadap air Dharma tersebut. Adanya pengaruh positif dan signifikan variabel kualitas produk, harga dan promosi ini juga di dukung dengan hasil R Square pada Koefisien Determinasi sebesar 31.0\% dan sisanya $69.0 \%$ di pengaruhi oleh faktor-faktor lain diluar variabel yang digunakan dalam penelitian ini.

\section{PENUTUP}

\section{Kesimpulan}

1) Kualitas produk memberikan pengaruh yang positif dan signifikan terhadap keputusan pembelian pada AMDK merek Dharma. Hal ini menunjukan bahwa semakin meningkat kualitas produk yang diberikan perusahaan, maka akan membuat konsumen untuk melakukan pengambilan keputusan dalam melakukan pembelian pada AMDK Merek Dharma.

2) Harga memberikan pengaruh yang positif tetapi tidak signifikan terhadap keputusan pembelian pada AMDK Merek Dharma. Hal ini menunjukan bahwa semakin sesuai harga dengan kualitas produk yang dirasakan oleh konsumen, maka akan membuat 
konsumen untuk melakukan pengambilan keputusan dalam melakukan pembelian pada AMDK Merek Dharma.

3) Promosi memberikan pengaruh yang positif dan signifikan terhadap keputusan pembelian pada AMDK Merek Dharma. Hal ini menunjukan bahwa semakin meningkat promosi yang diberikan oleh perusahaan, maka akan membuat konsumen untuk melakukan pengambilan keputusan dalam melakukan pembelian pada AMDK Merek Dharma.

4) Kualitas produk, harga, dan promosi mempunyai pengaruh yang positif dan signifikan secara bersama-sama terhadap keputusan pembelian. Hal ini menunjukan, apabila peningkatan kualitas produk, harga, dan promosi secara terus-menerus dan bersama-sama akan memberikan pengaruh yang positif terhadap keputusan pembelian.

\section{Saran}

1) Bagi perusahaan, khususnya perusahaan AMDK Merek Dharmabahwa kualitas produk dan harga yang diberikan oleh perusahaan AMDK Merek Dharma sudah memberikan kualitas dan manfaat yang baik terhadap keputusan pembelian konsumen AMDK Merek Dharmadi Kabupaten Sumbawa, akan tetapi dalam hal ini bukan berarti kualitas produk, harga, dan promosi yang ditetapkan berhenti disini saja, mengingat banyaknya pesaing dipasaran yang dihadapi oleh AMDK Merek Dharmamaka perusahaan harus tetap melakukan beberapa hal sehingga nantinya diharap konsumen memiliki persepsi yang cukup baik terhadap kualitas produk, harga, dan promosi yang dimiliki oleh AMDK Merek Dharma, diantaranya yang dapat dilakukan oleh AMDK Merek Dharmaadalah:

a) Meningkatkan kualitas produk dari event-event yang diadakan oleh AMDK Merek Dharmasehingga banyak konsumen yang melihat sebagai kepedulian yang positif dan meningkatkan perhatian konsumen khususnya di Kabupaten Sumbawa.

b) Perusahaan harus dapat menetapkan harga yang lebih kompetitif sehingga dapat dijangkau oleh semua konsumen dan lebih menerapkan lagi promosinya agar produknya dapat di kenal lagi oleh masyarakat khususnya di Kota Sumbawa.

c) Perusahaan tetap menjaga mutu dan kualitas yang telah dimilikinya selama ini dengan cara pengelolaan sumber daya produksi dan sumber daya manusia yang lebih efektif dan efesien, sehingga mampu bersaing dengan perusahaan sejenis lainnya.

d) Persepsi harga yang telah ditetapkan oleh perusahaan harus ditinjau, hal ini perlu diperhatikan mengingat pada saat ini tingkat persaingan untuk bisnis ini cukup tinggi, sehingga perusahaan harus terus meninjau kembali persepsi harga yang lebih baik tanpa mengurangi kualitas/mutu dari suatu produk itu sendiri.

2) Bagi masyarakat, diharapkan untuk lebih selektif lagi dalam memilih suatu produk untuk dapat dikonsumsi hal ini dikarenakan banyaknya persaingan antar produsen 
untuk dapat memenuhi pasar. Serta diharapkan masyarakat dengan ini dapat menambah pengetahuan serta wawasan berkaitan tentang kualitas produk, harga, dan promosi yang dimiliki oleh Dharma sebagai salah satu perusahaan AMDK di Kabupaten Sumbawa.

3) Bagi penelitian ini diharapkan dapat dijadikan referensi untuk penelitian selanjutnya. Penelitian ini masih memiliki banyak kekurangan. Peneliti selanjutnya dapat menambahkan variabel bebas lainnya yang dapat memberikan pengaruh pada keputusan pembelian sehingga mampu memberikan hasil penelitian yang lebih baik lagi.

\section{Daftar Pustaka}

Abdullah, T. (2016). Manajemen Pemasaran. Jakarta: Rajawali.

Alma, B. (2013). Manajemen Pemasaran dan Pemasaran Jasa. Bandung: Alfabeta.

Arikunto, S. (2012). Prosedur Penelitian Suatu Pendekatan Praktis. Jakarta: Rineka Cipta.

Fajar, L. (2015). Manajen Pemasaran Pendekatan Praktis. Yogyakarta: Graha Ilmu.

Faroh, Wahyu, N. (2017). "Analisa Pengaruh Harga, Promosi, dan Pelayanan Terhadap Keputusan Pembelian (Studi Pemasaran Online Melalui Jejaring Sosial Facebook Perawatan Wajah)". Jurnal Ilmiah Prodi Manajemen Universitas Pamilung, Vol. 4, No.2.

Ghazali, I. (2009). Aplikasi Analisis Multivariat Dengan Program SPSS. Semarang: Badan Penerbit Universitas Diponegoro.

Ghazali, I. (2013). Aplikasi Analisis Multivariate dengan Program IBM SPSS. Semarang: Badan Penerbit Universitas Diponegoro.

Kotler, P \& Armstrong,G. (2009). Prinsip-Prinsip Pemasaran Edisi 13 Jilid 1. Jakarta: Erlangga. Kotler, P \& Keller, L. K. (2009). Marketing Manajemen 13. New Jersey: Pearson Printice Hall. Kristanto, J. (2016). Manajemen Pemasaran Internasional. Jakarta: Erlangga.

Lupiyoadi, R. (2013). Manajemen Pemasaran Jasa. Edisi Ketiga. Jakarta: Selemba Empat.

Lutfianih, A, N. (2017). "Pengaruh Harga dan Kualitas Produk Terhadap Keputusan Pembelian Air Mineral Merek Wahdah Water dalam Prespektif Syariah di Kabupaten Gowa", Skripsi Universitas Islam Negeri Alaudin Makasar.

Porter, M. (2014). Manajemen Strategi. Jakarta: Simon.

Pratiwi, Mila, Y. (2017). "Pengaruh Harga, Promosi Dan Citra Merek Terhadap Keputusan Pembelian Sepatu Beat". Jurnal Manajemen Pemasaran Petra, Vol. 2 Nomer 1.

Putra, Giordo, P. (2016). "Pengaruh Kualitas Produk Terhadap Keputusan Pembelian dan Dampaknya Terhadap Kepuasaan Konsumen" (Survei pada Mahasiswa Administrasi Bisnis Fakultas Ilmu Administrasi Angkatan 2013 Dan 2014 Universitas Brawijaya yang melakukan Pembelian Paket Data Kampus). Jurnal Administrasi Bisnis (JAB), Vol. 48 No.1. 
Rawung, Dhio, R. (2015). “The Analysis Of Products Quality, Brrand And Price On Purcahse Decision In Motorcyle Suzuki PT. Sinar Galesong Pratama Manado", Jurnal Strategi Pemasaran, Vol. Nomor2.

Saladin, D. (2008). Manajemen Pemasaran Analisis, Perencanaan, Pelaksanaan, dan Pengendalian.

Saladin, D. (2016). Intisari Pemasaran \& Unsur-unsur Pemasaran. Bandung: Linda Karya.

Setiadi, N. (2011) Perilaku Konsumen. Jakarta: Kencana Prenada Media.

Setiawan, W. (2014). Strategi Pemasaran. Bandung: Veteran.

Sofian, A. (2011). Manajemen Pemasaran. Jakarta: Rajawali Pers.

Sugiyono. (2014). Metode Penelitian Pendidikan (Pendekatan Kuantitatif, Kualitatif, dan RED). Bandung: Alfabeta.

Sugiyono. (2016). Metode Penelitian Kuantitatif Kualitatif Kombinasi (Mixed Methods). Bandung: Alfabeta.

Swastha, B. (2010). Manajemen Pemasaran, Analisa Perilaku Konsumen. Edisi Pertama, Cetakan Ketiga. Yogyakarta: Liberty.

Tanzeh, A. (2012). Pengantar Metode Penelitian. Yogyakarta: Teras.

Tjiptono, F,. Candra, G. (2011). Service, Quality E Satisfaction. Yogyakarta: CV. Andi Offise.

Tjiptono, F. (2008). Pemasaran Strategik. Yogyakarta: CV. Andi Offset.

Tjiptono, F. (2015). Service Management Mewujudkan Layanan Prima. Yogyakarta: CV. Andi Office.

Umar, H. (2010). Riset Pemasaran dan Perilaku Pemasaran. Jakarta: Gramedia Pustaka Utama.

Umar, H. (2013). Riset Akuntansi. Jakarta: Gramedia Pustaka Utama.

Utami, H. (2013). Metode Penelitian untuk Skripsi dan Thesis Bisnis. Jakarta: Edisi Kedua Raja Grafindo Persada.

Wangean, Ryanto, H. (2014). “Analisis Citra Merek, Kualitas Produk dan Harga Pengaruhnya Terhadap Keputusan Pembelian Konsumen Pada Mobil All New Kia Rio Di Kota Manado", Jurnal BA, Vol. 2 Nomer 3.

Wiratma S. (2015). Metedelogi Penelitian Bisnis dan Ekonomi. Yogyakarta: Pustaka Baru Press. 